\title{
PROCESSOS TRABALHISTAS, CULTURA E NATUREZA (AMAZÔNIA, DÉCADAS DE 1970 E 1980) ${ }^{1}$
}

\author{
Nelson Tomelin Jr.* \\ Universidade Federal do Amazonas - UFAM \\ nelsontomelin@yahoo.com.br \\ Maria do Rosário da Cunha Peixoto** \\ Pontifícia Universidade Católica de São Paulo - PUC-SP \\ rosario.peixoto@hotmail.com
}

\begin{abstract}
RESUMO: Este artigo se propõe apreender dimensões de conflito na formação da propriedade e dos latifúndios na Amazônia a partir de práticas de derrubada da floresta e constituição de relações precárias de trabalho na região durante a ditadura civil-militar de 1964. As análises aqui desenvolvidas partem de conjunto documental da Justiça Trabalhista do estado do Amazonas, com foco para autos judiciais produzidos nas décadas de 1970 e 1980 pela Junta de Conciliação e Julgamento do município de Itacoatiara. Buscamos a partir desses processos trabalhistas surpreender articulações sociais amplas entre a imposição de práticas degradantes de trabalho e a destruição da natureza, em campo institucional marcado pela disputa e resistência de trabalhadores e trabalhadoras.
\end{abstract}

PALAVRAS-CHAVE: Amazônia, latifúndio, processos trabalhistas, ditadura civil-militar de 1964.

1 O presente artigo é resultado parcial do projeto "CIDADE, CULTURA E SAÚDE: processos trabalhistas, modos de vida, trabalho e resistência de trabalhadores em Itacoatiara (1973/2004)", pesquisa, em andamento, financiada no âmbito do edital UNIVERSAL AMAZONAS/FAPEAM. A apresentação das discussões aqui propostas deve-se a um esforço de ampliação de perspectivas comuns de trabalho com professores da Pontifícia Universidade Católica de São Paulo, em cooperação institucional através do PROCAD/CAPES “Trabalho, Cultura e Cidade” (PUCSP/UFAM/UFCG). À Professora Francisca Deusa Sena da Costa, Chefe do Núcleo do Centro de Memória da Justiça do Trabalho da $11^{\mathrm{a}}$ Região (CEMEJ/TRT $11^{\mathrm{a}}$ Região), e demais integrantes da equipe desse importante arquivo de Manaus, agradecemos pelo acesso facilitado ao acervo, e recepção sempre cordial. Pelo apoio técnico e de pesquisa, somos igualmente gratos à Sarah dos Santos Araújo, Jennifer Dayanna Carvalho Neves, Tamir Regina da Silva Carvalho e Avelino Pedro Nunes Bento da Silva.

* Professor do Departamento de História e do Programa de Pós-Graduação em História da Universidade Federal do Amazonas (UFAM/Manaus, AM). Doutor em História Social pela Universidade de São Paulo.

** Professora do Departamento de História e do Programa de Estudos Pós-Graduados em História da Pontifícia Universidade Católica de São Paulo (PUC-SP). Doutora em História Social pela Universidade de São Paulo. 


\title{
LABOR PROCESSES, NATURE AND PROPERTY (AMAZON, DECADES OF 1970 AND 1980)
}

\begin{abstract}
This article applies to fundamental and conflict aspects in the formation of property and large estates in the Amazon from practices of forest derogation and the establishment of precarious working relationships in the region during the civil-military dictatorship of 1964. The analyzes here are developed from the documental set of the Labor Justice of the state of Amazonas, focusing on judicial proceedings produced in the 1970s and 1980s by the Conciliation and Trial Board of Itacoatiara. We seek from these labor processes to surprise broad social articulations between the imposition of degrading practices of work and the destruction of nature, in an institutional field marked by the dispute and resistance of workers.
\end{abstract}

KEYWORDS: Amazon, large estate, labor processes, civil-military dictatorship of 1964.

\section{INTRODUÇão}

A documentação de que tratamos neste artigo abre espaço para pensarmos a expansão latifundiária e seu acelerado avanço sobre a floresta amazônica durante a ditadura civil-militar (1964-1985). Pretendemos, a partir de um conjunto de ações judiciais trabalhistas apresentadas no período de 1973 a 1980 à Junta de Conciliação e Julgamento de Itacoatiara, ${ }^{2}$ município vizinho à cidade de Manaus, no estado do Amazonas, problematizar temas como natureza, formação social da propriedade, trabalho e cultura. Buscamos, igualmente, discutir o processo contínuo de segregação de trabalhadoras e trabalhadores da reprodução de seus modos próprios de vida junto a terra e à mata ao longo daquela ditadura na região. As representações ideológicas de "recursos abundantes" supostamente facilitados pela exuberância natural do lugar são também alvo das nossas objeções.

Analisamos reclamatórias judiciais em primeira instância que expõem casos de derrubadas da mata em amplo e contraditório processo de constituição de espaços de trabalho, articulada reciprocamente a esse movimento a própria formação da cidade.

2 Os processos trabalhistas do período de 1973 a 1980 da antiga Junta de Conciliação e Julgamento (JCJ-ITA), posterior Vara do Trabalho do Município de Itacoatiara, compõem conjunto documental preservado pelo Centro de Memória da Justiça do Trabalho da $11^{a}$ Região (CEMEJ/TRT $11^{a}$ Região) de Manaus, alcançando o ano de 2004 nesse acervo. A revalorização desses processos trabalhistas como fonte histórica persegue o propósito de serem leitura fundamental e acessível para a própria classe trabalhadora, consolidando-se tais acervos como importante espaço de luta no campo da memória. 


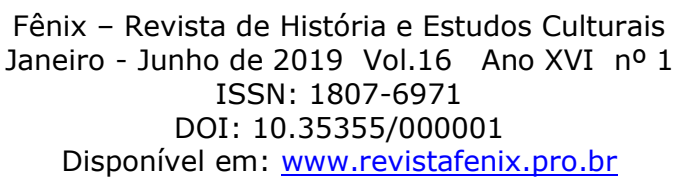

Evidenciam-se igualmente nesses processos dimensões de resistência social, sendo expressiva, contudo, a correlação desigual de forças entre trabalhadores e classe dominante, alinhando num mesmo campo dialético a exploração do trabalho e a destruição da natureza, além de outras ameaças aos modos de vida de homens, mulheres, velhos e crianças de Itacoatiara. Consideramos a discussão ainda mais importante por tratar-se de região que aparece teoricamente marcada por reiteradas proposições temáticas em que natureza, cultura e trabalho surgem como categorias prévias de análise, ${ }^{3}$ sem encadeamentos processuais ou de reflexão sobre a sua formação. Assim, a migração aparece como tema recorrente expresso em imagens de "busca ambiciosa" por melhores condições de vida, a natureza emerge como reino biológico que "comanda o meio", e a floresta, por sua vez, como campo delimitado em "paisagens sem história". Todas essas imagens contêm limites ideológicos intrínsecos, como se a divisão entre o aqui e o logo adiante fossem "dadas". A natureza irrompe nesse ideário não como o território do trabalho, da transformação e da mudança, o meio social comum, ${ }^{4}$ mas sim como "isolamento", o "distante", local de chegada ou de partida, sem dimensões contraditórias na relação entre o homem e o espaço, o campo e a cidade ou perspectivas de um modo de vida global. ${ }^{5}$

A década de 1930, marcada pela ascensão de Getúlio Vargas ao poder por um golpe de Estado que alinharia a produção nacional nos termos liberais da ideologia da industrialização, será também o período da formação da justiça trabalhista no país

Sobre a importância de se repensar na pesquisa em história relações não dicotômicas entre teoria e prática, conf. CRUZ, Heloisa de Faria; PEIXOTO, Maria do Rosário da C.; KHOURY, Yara Aun. "Introdução". in: MACIEL, Laura Antunes; ALMEIDA, Paulo Roberto de; KHOURY, Yara Aun. Outras Histórias: memórias e linguagens. São Paulo: Olho d'água, 2006, pp. 09-21.

4 Acompanhamos neste artigo perspectivas de análise abertas por E. P. Thompson em seus trabalhos sobre a formação histórica de sentidos de "comum" e "tradicional" na Inglaterra do século XVIII, tendo evidenciado o autor nesses estudos a experiência de resistência de homens e mulheres trabalhadoras, em uma história vista a partir de baixo, o campo aberto daquelas disputas. Cf. THOMPSON, E. P. Costumes em comum: estudos sobre a cultura popular tradicional. São Paulo: Cia das Letras, 2002.

5 Importante reflexão sobre a construção dessas temáticas na região amazônica, articuladas criticamente no campo da ideologia do progresso, da integração, do vazio demográfico, e do desenvolvimento industrial, conf. em HARDMAN, Francisco Foot. O Trem Fantasma. A ferrovia madeira-mamoré e a modernidade na selva. São Paulo: Cia das Letras, 2005. Também os cineastas Jorge Bodanzky e Orlando Senna discutem perspectivas relevantes desses temas no filme Iracema, uma transa amazônica. Cf. BODANZKY, Jorge e SENNA, Orlando. Iracema, uma transa amazônica. (Filme, longa-metragem, 96 min). Produção: Stopfilme, 1974. 
(1931-1939). ${ }^{6}$ Não pretendemos afirmar aqui perspectivas de máculas de origem, ou homogeneizar tudo o que se fez ou faz historicamente nesse campo por aqueles pressupostos iniciais de corporativismo e conciliação de classes pelo governo varguista, verticalizados no Estado Novo (1937-1945). O que se observa na presente discussão é que, apesar de inúmeros esforços interpretativos sobre o período, no campo da sua problematização, a ideia do trabalho como produção de mercadoria, aparece como ponto pacífico, inquestionável, portanto, pela naturalização da concentração de terras e dos interesses privados. Ou, de outra forma, sob a ideologia do "salário", reduz-se o trabalho a uma experiência meramente passível de remuneração. ${ }^{7}$ Por último, o tema do trabalho surge nessas análises como prática especializada, com vistas à consecução de um fim, como categoria abstrata, livre e predisposto aos "contratos", em um mercado controlado pelo Estado, "livremente" precificado pela lei de oferta e procura. Daí a ausência de problematizações sobre o movimento contraditório e contínuo da divisão entre o público e o privado, pelo que também a terra aparece como tendo valor em si. A dinâmica dessa ideologia é sintetizada por Karl Marx em discussão importante de ser retomada aqui por se tratarem as nossas fontes documentais de autos judiciais trabalhistas.

Se um pressuposto do trabalho assalariado e uma das condições históricas do capital são o trabalho livre e a troca desse trabalho livre por dinheiro a fim de reproduzir e valorizar o dinheiro, a fim de ser consumido pelo dinheiro não como valor de uso para a fruição, mas como valor de uso para o dinheiro, outro pressuposto é a separação do trabalho livre das condições objetivas de sua realização - do meio de trabalho e do material de trabalho. Portanto, sobretudo a desvinculação do trabalhador da terra como seu laboratório natural em conseqüência, a dissolução da pequena propriedade livre de terras...8

A operação da justiça do trabalho em Itacoatiara no período aqui analisado partiu igualmente desses valores. Estranho, contudo, seria desconhecer esse processo como movimento marcado por resistências inúmeras, as quais evidenciam que o direito

6 Problematizamos mais adiante a constituição dessa legislação específica.

7 Para uma discussão mais ampliada desse tema, conferir, de Karl Marx, "Bastiat e Carey. Bastiat. Harmonies économiques”. in: MARX, Karl. Grundrisse. Manuscritos econômicos de 1857-1858. Esboços da crítica da economia política. São Paulo: Boitempo, 2011, p. 27.

8 MARX, Karl. Grundrisse. Manuscritos econômicos de 1857-1858. Esboços da crítica da economia política. São Paulo: Boitempo, 2011, p. 388. 


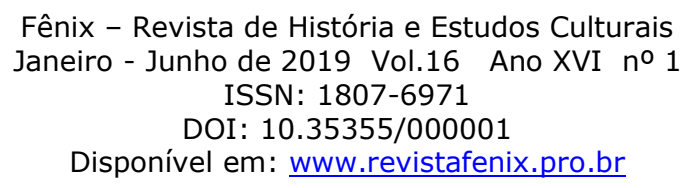

ao trabalho, e a terra, são "matéria" viva, em transformação num tempo histórico, conforme observa Walter Benjamin, "saturado de agoras". ${ }^{9}$ A documentação que ora analisamos apresenta correlações de poder na Amazônia que parecem legitimar judicialmente a terra como "propriedade privada". A ditadura civil-militar no Brasil teve papel preponderante na formação dos latifúndios na região amazônica, com violência destacada contra as populações indígenas, articulando práticas de destruição da natureza e de alteração profunda de modos de vida com a consolidação social de valores positivos quanto à exploração do trabalho. ${ }^{10} \mathrm{Ou}$ seja, a exploração do trabalho, sobretudo do trabalho indígena, campo de disputas no qual a justiça trabalhista cumpriu papel importante, foi condição sem a qual não haveria a formação daqueles latifúndios

Nessa mesma direção, Ariovaldo Umbelino de Oliveira e Camila Salles de Faria, referindo-se à invenção da propriedade privada da terra no Brasil, frisam que "de início deve-se sucintamente afirmar que a área territorial do país tem suas origens nos modos pelos quais os povos indígenas, através do estabelecimento de relações comunitárias de produção, desenvolveram suas culturas", ${ }^{11}$ e que a formação do território brasileiro, tal como o conhecemos, "é conseqüência do processo através do qual o capital submeteu a terra à sua lógica econômica de exploração". ${ }^{12}$ Nesse campo, portanto, as disputas de povos indígenas e quilombolas por demarcação de terras são formas de resistência contra a constituição de latifúndios, haja vista obstaculizarem dinâmicas históricas da exploração do trabalho. Buscamos surpreender nos processos que analisamos as faces antagônicas dessas lutas.

9 BENJAMIN, Walter. "Sobre o conceito de história". in: BENJAMIN, Walter. Obras Escolhidas, Vol. I. Magia e Técnica, Arte e Política. Ensaios sobre Literatura e História da Cultura. São Paulo: Brasiliense, 1996, p. 229.

10 Importante discussão desse tema, no que refere para os ataques sofridos por indígenas da região no período, realizou para o cinema o documentarista Vincent Carelli em Corumbiara. Cf. CARELLI, Vincent. Corumbiara (Longa-metragem/Documentário), 117 min., 2009.

11 OLIVEIRA, Ariovaldo Umbelino de e FARIA, Camila Salles de. O processo de constituição da propriedade privada da terra no Brasil. in: Encontro de Geógrafos de América Latina (Montevidéu), 12, 2009, p. $\quad$ s/n. $\quad$ Disponível em: http://observatoriogeograficoamericalatina.org.mx/egal12/Geografiasocioeconomica/Geografiaecono mica/94.pdf. Acesso em: 10 set. 2017.

12 Para o aprofundamento de reflexões sobre a formação histórica da propriedade relacionada a formas de trabalho e de resistências pela cultura, conf. CANDIDO, Antonio. Os Parceiros do Rio Bonito. Estudo sobre o caipira paulista e a transformação dos seus meios de vida. Rio de Janeiro: Ouro sobre Azul, 2011. 


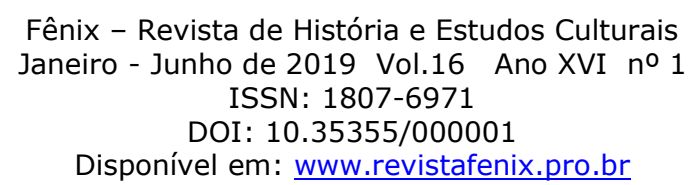

\section{A CONQUISTA DA NATUREZA}

Discutiremos neste artigo dimensões de conflitos em cidade portuária e de produção madeireira no estado do Amazonas, a partir de processos trabalhistas que envolvem "derrubadoras" da mata na região, a fim de problematizar temáticas sobre cultura, trabalho e natureza, bem como a produção de divisões nesse campo ao longo da ditadura civil-militar naquele momento.

O campo das atividades do extrativismo predatório na região não constitui o eixo central do que aqui propomos. De fato, nessa documentação são inúmeros os processos de trabalhadores do setor de extração do óleo de Pau Rosa, árvore de grande porte de que se extrai pela moagem do tronco essência de interesse de setores do mercado, inclusive internacional (prioritariamente indústrias farmacêutica e cosmética). Contudo, a série documental que fundamenta as problematizações aqui desenvolvidas compõe outro conjunto de processos da Junta de Conciliação e Julgamento de Itacoatiara envolvendo precisamente a derrubada da mata, sua "rebaixação" (sic.) e serviços de roçagem, atendendo-se a interesses de empresas, e do Estado articulado a esses setores, momento em que a ampliação do campo produtivo sobre a floresta surge, eventualmente, como "interesse de todos", conforme apontam as fontes analisadas a seguir. Os registros desses conflitos naquele foro trabalhista tratam da intrínseca relação entre a formação do capital e a conquista da natureza na região. Tudo devidamente contratado na letra da lei, sob os auspícios da justiça trabalhista. É desse contrato que aqui tratamos.

Em 24 de novembro de 1975, a Junta de Itacoatiara registra "termo de reclamação" do empreiteiro Carlos, ${ }^{13}$ "braçal, casado, brasileiro", ${ }^{14}$ contra V. F., proprietário da área verde desmatada.

Na disputa judicial requer-se "saldo de empreitada" no valor de Cr\$2.100,00, por trabalho realizado de 01 a 29 de setembro daquele mesmo ano. Somos informados que Carlos trabalhou como empreiteiro no "terreno denominado Guajarazinho, situado à

13 Estão citados sob pseudônimo os autores e parte reclamada dos processos trabalhistas analisados nesta pesquisa. A transcrição desses documentos acompanhou escrita e pontuação tal como aparecem nos originais.

14 Ao longo do texto, destacamos entre aspas as sumárias e muitas vezes únicas informações sobre o ramo profissional e condição de vida dos trabalhadores autores dessas demandas, observando no uso repetido do termo "braçal" perspectivas invisibilizadoras da luta de classes nesses processos. 
margem direita do lago Serpa, neste município", “em roçagem, derrubada e rebaixação de mata", em 30 hectares de terra $\left(300.000 \mathrm{~m}^{2}\right)$.

Em documentação anexada ao processo ficou descrito o contrato de trabalho estabelecido entre as partes para a execução daquelas tarefas de desmatamento:

Contrato particular de empreitada que entre si fazem Carlos, como empreiteiro, e V. F., como proprietário, na forma abaixo declarada: Pelo presente contrato particular de empreitada para desmatamento de uma área de 30 hectares de terras no terreno denominado "Guarajazinho", situado à margem direita do Lago da Serpa, neste município, de um lado como empreiteiro Carlos, brasileiro, casado, agricultor, residente e domiciliado nesta cidade, e, de outro lado como proprietário V. F., brasileiro, casado, comerciante, residente e domiciliado nesta cidade, sob as cláusulas e condições seguintes:

$1^{\mathrm{a}}$ - O primeiro contratante empreiteiro, obriga-se a executar para o segundo contratante proprietário, no terreno acima citado, de propriedade deste último os seguintes serviços: desmatamento, broca, derrubada, rebachamento e queima e demais outros serviços necessários e indispensáveis ao bom acabamento do terreno, que neste deixam de ser enumerados, mas que poderão serem exigidos pelo segundo contratante proprietário; Início em 01/09/75 e término em 30/09/75;

$2^{\mathrm{a}}-\mathrm{O}$ material necessário será fornecido pelo primeiro contratante empreiteiro;

$3^{\mathrm{a}}$ - O segundo contratante proprietário pagará a importância de 550,00 (quinhentos e cinquenta cruzeiros), por hectare, no total de 16.500,00 (dezesseis mil e quinhentos cruzeiros), pagáveis da seguinte maneira: no início do serviço 7.000,00 (sete mil cruzeiros); quinze dias depois 3.500,00 (três mil e quinhentos cruzeiros) e o saldo no término do contrato, se houver;

$4^{\mathrm{a}}$ - O primeiro contratante empreiteiro se obriga a entregar os 30 hectares de terras devidamente realizadas até o dia 30 de setembro do corrente ano, por justa causa, até o dia cinco (5) de outubro do mesmo ano, sob pena de pagar ao segundo contratante proprietário a multa de 500,00 (quinhentos cruzeiros), por dia que exceder daquele prazo;

$5^{\mathrm{a}}$ - O empreiteiro faculta ao proprietário a examinar ou vistoriar o serviço quando entender conveniente;

$6^{\mathrm{a}}$ - Qualquer responsabilidade com os trabalhadores, em caso de acidentes ou morte, inclusive obrigações com o INPS, Fundo de Garantia e demais previstas em Lei, correrão por conta do primeiro empreiteiro;

$7^{\mathrm{a}}$ - O presente contrato poderá ser rescindido em qualquer época, por mutuo acordo ou pelo segundo contratante proprietário, se justa causa houver, independentemente de qualquer notificação ou interpelação judicial ou extra-judicial, nos seguintes casos: $1^{\circ}$ - se o primeiro contratante empreiteiro deixar de cumprir qualquer item ou condições deste contrato; $2^{\circ}$ - por negligencia do primeiro empreiteiro; $3^{\circ}$ pelo primeiro contratante empreiteiro, se o segundo contratante 


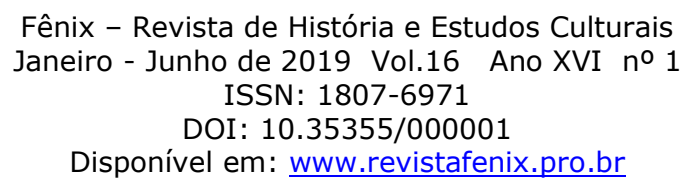

proprietário, deixar de cumprir qualquer item ou condições a que está obrigado.

Itacoatiara, $1^{\circ}$ de setembro de 1975. Carlos. V. F.

Assinatura (ilegível) de duas testemunhas.

Em tempo: Os contratantes elegem o foro desta Comarca, com renúncia de outro qualquer para quaisquer questões oriundas do presente contrato.

Em audiência realizada no dia 01 de dezembro de 1975, conciliam os interessados em Cr\$1.000,00, com a observação de que demais saldos já haviam sido honrados, pois "em contestação disse o reclamado que nada deve ao reclamante, pois conforme o contrato escrito, já lhe pagou o lhe era devido".

Chamam a atenção nesses processos da Junta de Itacoatiara - em período de forte acirramento entre latifundiários, agricultores e populações tradicionais do território amazônico - a rapidez e facilidade com que ajustes são conciliados, ou arquivados, sem maiores problematizações pela arbitragem judicial quanto àquelas ameaças ao modo de vida de trabalhadores da região: desmatamentos, concentração de terras, e demais violências. Importante dimensionar ainda nesse meio as "pequenas" empreitadas de derrubada da mata. São processos que se acumulam no período analisado, possibilitando reflexões sobre a dinâmica de formação de lattifúndios na Amâzônia, os quais podem, eventualmente, terem sido constituídos de maneira fragmentária, com a anexação progressiva de pequenas glebas de terra. ${ }^{15}$

Em 06 de dezembro de 1977, é autuada na Junta de Itacoatiara reclamação de Paulo contra S/A Fazenda Boa Vista, questionada em séries expressivas de processos trabalhistas naquele foro. Informa o trabalhador ter prestado serviço para a referida empresa entre setembro e novembro de 1976, "em regime de empreitada; que cada hectare de terra derrubada e roçada foi acertado em 500,00; que fez 5 hectares [50.000

15 A grilagem de terras na Amazônia apresenta dinâmicas diversas, inclusive com a formação de "megalatifúndios", a exemplo do Projeto Jari, gleba de empresa privada de capital nacional e estrangeiro que ao longo da década de 1960 acumulou, pelo que se suspeita, dadas as difíceis condições de se apurarem tais números, de seis a oito milhões de hectares. Conf. CAMARGO, Maria Luíza G. de. O Latifúndio do Projeto Jari e a propriedade da terra na Amazônia brasileira. Dissertação de Mestrado. USP, FFLCH, São Paulo, 2015. Quanto aos métodos utilizados nesses processos de concentração ilegal de terras, e resistências interpostas, também há diferenças. Na década de 1980, o grupo estatal francês de exploração de petróleo Elf-Aquitaine, em ação criminal apresentada por indígenas Sateré-Mawé, é acusado pela morte de quatro moradores da Terra Andirá-Marau, intoxicados por conteúdo químico de material explosivo deixado pela empresa na área, associada ainda a estratégia de invasão à destruição daquela fauna e flora. A memória viva desse enfrentamento se articula no tempo presente pela continuidade de outras lutas de mulheres indígenas Sateré-Mawé da cidade de Manaus. Conf. MIRANDA, Vanessa. Mulheres indígenas na cidade: cultura, saúde e trabalho (Manaus, 1995-2014). Dissertação de Mestrado. FIOCRUZ, Manaus, 2015. 
$\mathrm{m}^{2}$ ]; que recebeu uma parte da empreitada ficando com o saldo de 785,00”. Agendada a audiência de conciliação e julgamento, deixa de comparecer o trabalhador, "presente a reclamada por meio de seu Diretor-Presidente”. O arquivamento da reclamatória, sem maiores questionamentos, ou "divergência de votos", refere-se a entendimentos que orientam o cotidiano daquelas decisões judiciais trabalhistas.

Itacoatiara, à luz dessa documentação, surge como idílico espaço social do trabalho, sem conflitos mais contundentes no que tange ao direito à vida e sua reprodução pelos trabalhadores por seus próprios meios. A máxima amazônica, adágio da ideologia dominante ainda presente, de que na região "só passa fome quem quer", encontra resguardo judicial na celeridade e encaminhamentos conciliatórios dessas audiências. Tudo se passa como se não houvesse conflitos de terras, fome, luta de classes, exploração do trabalho, trabalho escravo e infantil, destruição de modos de vida, sobretudo dos indígenas da região. A documentação analisada sugere, por vezes, caracterizarem-se essas audiências como negociação direta entre patrões e trabalhadores, modelo liberal-voluntarista em lugar da arbitragem dos conflitos de classes pelo Estado. ${ }^{16}$ Observa-se nesse terreno a prerrogativa do negociado sobre o legislado, ${ }^{17}$ sendo legitimados aí acordos muitas vezes estabelecidos fora dos autos e do tribunal, como sugere a enorme quantidade de "desistências" de trabalhadores, denunciada inclusive por operadores daquela Junta como eventuais tentativas de obstrução da justiça por pressão dos patrões reclamados nesses processos. ${ }^{18}$

Em 1973, Lucindo, trabalhador "braçal, casado, brasileiro", reclama contra E. S. vencimentos de "auxílio de doença" e "assinatura de carteira". Informa o autor da

16 Desdobramentos e compreensões teórico-metodológicas no tratamento desse tema, conf. SILVA, Fernando Teixeira da. Trabalhadores no tribunal: conflitos e justiça do Trabalho em São Paulo no Contexto do Golpe de 1964. São Paulo: Alameda, 2016, pp. 40-45 e GOMES, Ângela de Castro e SILVA, Fernando Teixeira da (org.) A Justiça do Trabalho e sua história: os direitos dos trabalhadores no Brasil. Campinas: Editora Unicamp, 2013.

17 Também o golpe de 12 de maio de 2016, perpetrado com a aceitação pela Câmara Federal de fraudulento processo de impeachment contra a presidenta Dilma Rousseff, tem posto em prática alterações na legislação trabalhista e função da Justiça do Trabalho no Brasil, secundarizando-se fundamentalmente o papel da arbitragem judicial frente ao negociado em acordos coletivos de trabalhadores com empresas, passando para um segundo plano os direitos previstos pela Constituição Federal e Consolidação das Leis Trabalhistas (conf. Lei n 13.467 , de 13 de julho de 2017).

18 Com foco em diferentes temáticas e período, a partir de outros processos trabalhistas dessa mesma localidade, publicamos artigo em que tais aspectos são acompanhados. Conf. TOMELIN Jr., Nelson e PEIXOTO, Maria do Rosário da Cunha. Histórias e justiça em processos trabalhistas: cultura de resistência de trabalhadores na Amazônia brasileira. Projeto História, São Paulo, n. 58, pp. 298-326, jan.-mar. 2017. 
ação, em reclamação verbal, "que sofreu acidente no trabalho no dia 01 de junho de 1973. Que não voltou ao serviço". Da audiência de 18 de setembro do mesmo ano, sabemos que,

Em contestação disse o preposto da reclamada que não existe relação de emprego daí ser improcedente a reclamação. O que houve foi o seguinte: anualmente os moradores da redondeza se reúnem para desobstruir o igarapé do cavalo. Assim todos colaboram, os que possuem motores cedem-no; os que só possuem mão-de-obra com esta colaboram. O interesse portanto na limpeza do igarapé é de todos. Sendo assim o reclamado que possui embarcação também participou dessa espécie de mutirão; outros proprietários de embarcação que, por qualquer motivo não podiam se fazer presente com as mesmas, davam a sua parcela de colaboração em dinheiro a fim de que fossem adquiridos gêneros alimentícios, como também gratificação do pessoal que lá trabalhava; que no dia do acidente que ocorreu com o reclamante este prestava serviço em uma embarcação pertencente à ACAR-AM - Associação de Crédito e Assistência Rural do Amazonas. Como se vê o reclamante não se encontrava prestando serviço diretamente ao reclamado; que não obstante isso a Prefeitura de Itacoatiara custeou todas as despesas de hospital com o reclamante; inclusive cerca de 30 dias de internamento hospitalar.

Do interrogatório do trabalhador Lucindo, ficou anotado

que na semana seguinte não trabalhou; que além da embarcação do reclamado, outras duas deram sua colaboração na limpeza do igarapé, além do auxílio prestado pela embarcação da ACAR-AM durante dois dias; que no dia do acidente o reclamante prestava serviço na embarcação da ACAR-AM; que outros proprietários de embarcação não podiam colaborar pessoalmente davam de $\mathrm{Cr} \$ 100,00$ a $\mathrm{Cr} \$$ 50,00, que durante dois dias o reclamante recebeu a diária de $\mathrm{Cr} \$$ 10,00 e nos demais a diária foi paga a razão de $\operatorname{Cr} \$ 8,00$; que o reclamante prestou exatamente 12 dias de serviço uma vez que trabalhou a $1^{\text {a }}$ semana, faltou a segunda, e acidentou-se no meio da terceira; que a Prefeitura colaborou ainda com um tambor de óleo; que acha que foram consumidos no serviço três tambores de combustível; que o senhor E. S. é fazendeiro e comerciante; que o igarapé do cavalo serve a todos indistintamente; que juntamente com o depoente trabalhavam mais três homens sendo que um deles era o motorista da embarcação e empregado do reclamado; que sabe que a Prefeitura forneceu medicamento; quanto ao internamento hospitalar não sabe se a Prefeitura custeou as despesas a ele referentes, pois o médico do hospital disse ao depoente que não se preocupasse com pagamento, que passou 32 dias internado no hospital. $\mathrm{O}$ reclamante arrolou testemunha, L. M. S. 
O processo em questão evidencia relações de reciprocidade na formação do campo social do trabalho articulado com o espaço da floresta e modos de vida da cidade. Da conciliação, uma semana após essa audiência, paga o fazendeiro e comerciante E. S. a quantia de $\operatorname{Cr} \$ 50,00$, frente aos $\operatorname{Cr} \$ 400,00$ fixados previamente pela Junta, e, mesmo assim, "a título de liberalidade uma vez que se reconhece não haver existido a relação de emprego". Difícil provar o vínculo empregatício quando se reconhece o trabalho como "interesse de todos", "colaboração recíproca", "os que possuem motores cedem-no; os que só possuem mão-de-obra com esta colaboram". Observa Kazumi Munakata, em obra de referência sobre a temática, A legislação trabalhista no Brasil, as raízes desse liberalismo corporativista, pelo qual se defende que "todo indivíduo tem a propriedade do seu corpo, de suas capacidades e, por isso mesmo, todos os homens, considerados individualmente, são iguais entre si, são todos proprietários". ${ }^{19}$ Ao fim e ao cabo, esvaziada de seu conteúdo social, a propriedade aparece como dimensão essencial do indivíduo.

Observa-se desse processo dinâmica de formação do mercado de trabalho "terceirizado", presente em séries dessas reclamações no período, eventualmente com o apoio da justiça, que ao desconhecer muitas vezes tais vínculos empregatícios reduz o montante arrolado daquelas demandas. A Prefeitura, responsável no caso pela limpeza do igarapé, gestora do suposto mutirão, em que trabalhadores e fazendeiros aparecem lado a lado, num campo social que por essa narrativa se pretende comum, livre de conflitos ou contradições. Não sabemos absolutamente nada sobre o acidente, grave ao que parece, uma vez que leva o trabalhador à internação de 32 dias. Tampouco temos o depoimento que prestaria a testemunha arrolada pelo trabalhador, pois que a conciliação se deu na abertura da segunda audiência.

De todo modo, vale destacar a existência de outra ação contra o mesmo fazendeiro, movida por trabalhador de igual sobrenome da testemunha arrolada por Lucindo, evidenciando relações de solidariedade, e outras formas de luta e comunicação, ainda que não organizadas. O conjunto desses processos, nesse e em outros períodos, apresenta relações cruzadas de associação entre seus autores,

19 MUNAKATA, Kazumi. A Legislação Trabalhista no Brasil. São Paulo: Brasiliense, 1981, p. 11. A respeito do tema da formação da Justiça do Trabalho no Brasil, veja-se também VARUSSA, Rinaldo José. Trabalhadores e a Construção da Justiça do Trabalho no Brasil (décadas de 1940 a 1960 ). São Paulo: LTr, 2012. 
evidenciadas em endereços e sobrenomes que se repetem nos autos. Aventamos a hipótese de que a comunicação advinda dessa vizinhança de interesses e valores traça perfis comuns de solidariedade entre os trabalhadores que então acessaram a Junta de Itacoatiara. Luiz, trabalhador "braçal, casado, brasileiro" reclama sobre um mês de trabalho, a quantia de Cr\$62,50. A Junta fixa em Cr\$150,00 o valor da causa, finalmente conciliada em $\mathrm{Cr} \$ 30,00$, com o mesmo argumento da inexistência de vínculo empregatício. No caso presente, contudo, tratava-se de trabalhador "proprietário de embarcação", reforçando no processo a versão do "mutirão" de "colaboração para desobstruir o igarapé do cavalo". Poder público e justiça apropriam-se do termo mutirão esvaziando-o de seu conteúdo e significado histórico, o de uma prática de colaboração entre trabalhadores cujos termos eram estabelecidos por eles próprios.

Maria Sylvia de Carvalho Franco, em Homens livres na ordem escravocrata, discute a participação do Estado na organização de espaços de trabalho pela imposição a núcleos comunitários - "bairros caipiras" - de tarefas do tipo que "interessam a todos", como a abertura de estradas no século XIX. Observa ainda que, nessa dinâmica, "o mutirão difere fundamentalmente da cooperação que aparece nas formas modernas de organização do trabalho, as quais trazem implícitos o controle e a disciplina". ${ }^{20}$ Vale ainda a citação da autora em trecho que analisa proposta de projeto de vereador transcrito nas Atas da Câmara Municipal de Guaratinguetá. Apesar de extensa, esclarece a passagem aspectos das discussões que aqui propomos.

Procurando resolver o crônico problema de construção e conservação de estradas, um dos vereadores da Câmara de Guaratinguetá, em 1897, apresenta uma indicação para regular a matéria, onde se lê:

"Art. $3^{\circ}$ - Todas as estradas municipais e vicinais serão feitas de mão comum pelos moradores do bairro e pelos vizinhos que dela se utilizarem;

"Art. $6^{\circ}$ - Para o serviço das estradas municipais será avisado e obrigado a comparecer todo indivíduo que trabalhe por suas mãos em serviços de roça, quer seja agregado, jornaleiro, meeiro, colono nacional ou estrangeiro residente no respectivo bairro;

"§ único - os fazendeiros concorrerão com a quarta parte dos seus trabalhadores não domiciliados no bairro.

"Art. $12^{\circ}$ - O inspetor, quando não puder pessoalmente fazer os avisos para os trabalhos anuais ou extraordinários, poderá encarregar duas

20 FRANCO, Maria Sylvia de Carvalho. Homens livres na ordem escravocrata. São Paulo: Unesp, 1997, p. 31. 
pessoas para conjuntamente o fazerem. Essas duas pessoas ficam dispensadas de trabalhar na reunião para que convidarem.

"Art. $13^{\circ}$ - Concluídos os serviços e obras da estrada, o respectivo inspetor comunicará ao fiscal, remetendo uma relação dos trabalhadores que concorreram para os trabalhos e outra dos que deixaram de concorrer. Servirá de prova de notificação, a declaração, sob palavra de honra, dos dois encarregados da intimação, ou o ofício do inspetor, quando houver intimado pessoalmente".

Com força e nitidez este documento projeta a visão do homem pobre na consciência da camada dominante. Ela o aproxima do escravo e estabelece uma desigualdade, às escancaras, entre o proprietário e o homem sem posses, distinguindo a natureza dos encargos a que estariam legalmente sujeitos. Entretanto, essa mesma visão compreende a solicitação desse homem pobre para ações que pressupõem o reconhecimento de seus atributos humanos em sua expressão máxima: aceita-se, para efeitos legais, a sua palavra de honra. Note-se também como um padrão tradicional - o trabalho coletivo - é reelaborado, transformando-se a participação nos grupos de ajuda mútua em canal para a dominação e convertendo-a em lei. $\mathrm{O}$ cruzar de novos e velhos padrões, reforçando o processo de dominação, também se observa nos artigos (não transcritos acima) que prevêem multas e cadeia para as transgressões e que obrigam o servidor a autoprover-se com sustento e ferramentas. Assim, o projeto cria impostos que se traduzem por serviços pessoais do cidadão, com a pena restritiva de sua liberdade quando não puder remir-se a dinheiro, e também o supõe possuidor de meios de subsistência e de instrumentos de trabalho. Ei-lo, pois, como contribuinte do Estado, sujeito a um emaranhado de tributos que atingem tanto sua pessoa como sua propriedade, refletindo a posição de servo temporário que lhe é atribuível, combinada com sua velha condição de produtor independente. ${ }^{21}$

A leitura dessa proposta apresentada à Câmara de Guaratinguetá, herdeira dos pressupostos que orientaram as relações de trabalho no país ao longo da escravidão, faz pensar sobre dimensões do ligeiro e alinhado entendimento da Junta de Itacoatiara em mediação favorável ao poder público e aos empreiteiros do lugar, com a tese de que agia o trabalhador por interesse próprio, e "que não obstante isso a Prefeitura de Itacoatiara custeou todas as despesas de hospital com o reclamante". A ressalva de que deveria, por certo, o trabalhador agradecer por não precisar se preocupar "com o pagamento" daquela internação hospitalar reforça lógicas clientelistas e de favor nesses processos, a despeito da defesa de seus direitos. Articulam-se nessa demanda trabalhista, na Amazônia de 1973, temas da formação da ideia de natureza comum relacionada à exploração do trabalho e saúde dos trabalhadores.

21 FRANCO, Maria Sylvia de Carvalho. Homens livres na ordem escravocrata. São Paulo: Unesp, 1997, pp. 105-106. 
Em 04 de fevereiro de 1974, Lauro reclama na Junta de Itacoatiara "aviso prévio, gratificação natalina, férias proporcionais, auxílio doença, FGTS”. Trabalhador "braçal, casado, brasileiro", informa ter iniciado o trabalho para O. M. em 14 de janeiro daquele ano, "percebendo o salário diário de $\mathrm{Cr} \$ 10,00$, pagos por quinzena, trabalhava no serviço de roçagem de matas”. Lauro adoece cinco dias após a contratação, quando se afasta do serviço "por não poder trabalhar". Declara, por fim, que a reclamada não lhe prestou qualquer assistência, tendo antes lhe dispensado "sem justa causa". Além de quinze dias de auxílio-doença, no valor de $\operatorname{Cr} \$ 150,00$, requer o pagamento dos demais valores ilíquidos, totalizando $\mathrm{Cr} \$ 533,32$. Concilia em 150,00 cruzeiros. Impressionam aqui, ainda outra vez, a celeridade do processo, bem como a ausência de problematizações judiciais em torno do seu direito à assinatura de carteira e eventuais indenizações (não sabemos sobre o acidente sofrido). Para os fins que discutimos neste texto, importa observar ainda - o que se repete à exaustão em ações trabalhistas envolvendo roçagem e derrubada de matas - o fato de não se questionar sobre a propriedade dessas terras, se área de grilagem ou invasão, ou quanto à questão do desmatamento em si, como se a natureza, ou o campo, relação alguma tivessem com perspectivas históricas do direito ao trabalho e à cidade.

O crítico literário inglês Raymond Williams problematiza em sua obra processos de construção de "ideias sobre a natureza", as quais contém, "embora muitas vezes de forma desapercebida", conforme lembra o autor, "uma quantidade extraordinária da história humana". ${ }^{22}$ E continua: "parece-me que o que é frequentemente argumentado na ideia de natureza é a ideia de homem, e isso não apenas de modo geral ou absoluto, mas a ideia do homem na sociedade e, de fato, as ideias de tipos de sociedade". ${ }^{23}$ Nessa direção, lembra Williams que "uma parte considerável do que chamamos de 'paisagem natural' possui a mesma história. Trata-se de um produto do planejamento e do trabalho humano e, ao ser admirado como natural, importa muito se suprimimos dele o trabalho ou se o reconhecemos". ${ }^{24}$ Raymond Williams enfatiza ainda dimensões reais do campo ideológico constitutivo do pensamento e reflexão sobre as "categorias" aí elencadas.

\footnotetext{
22 WILLIAMS, Raymond. "Ideias sobre a natureza". in: Cultura e Materialismo. São Paulo: Editora Unesp, 2011, p. 94.

23 Ibid., p. 94.

24 Ibid., p. 104.
} 


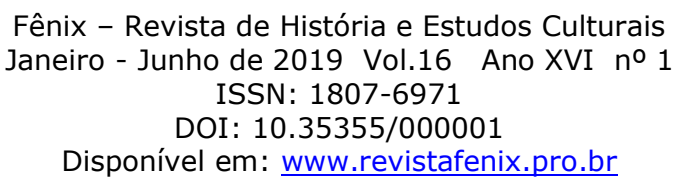

À medida que a exploração da natureza continuava em ampla escala, e sobretudo nos novos processos extrativos e industriais, as pessoas que conseguiam maior lucro voltaram-se (e foram bastante engenhosas) para uma natureza ainda virgem, para terras compradas e refúgios rurais. Desde então, passou a existir essa ambigüidade na defesa do que é chamado de natureza e das ideias associadas de conservação, em seu sentido fraco, e de reserva natural. Alguns a favor dessa defesa são os que melhor entendem a natureza, insistindo na criação de conexões e relações plenas. Mas um número significativo de pessoas a favor são, falando abertamente, hipócritas. Estabelecidos em posições de poder no próprio processo que cria a desordem, eles trocam as suas roupas nos finais de semana ou quando podem ir ao campo; participam de apelos e campanhas para manter verde e intocado um último pedaço da Inglaterra, e voltam espiritualmente refeitos para investir na fumaça e na destruição. ${ }^{25}$

Foi também nesse sentido que Raymond Williams, em $O$ Campo e a Cidade: na história e na literatura, propôs instigante reflexão sobre o tema da criação das paisagens e de uma "linguagem verde" nessas ideologias, tendo evidenciado em seu estudo o processo de formação da noção de natureza intocada, representação que deixa de relacionar aqueles outros lugares que precisaram ser maculados para que se constituíssem tais imagens do "meio ambiente" de fruição. ${ }^{26}$

Marilena Chaui ao associar os temas da "natureza" com o do "descobrimento", a partir da leitura de diários de bordo e correspondência dos "navegantes-descobridoresconquistadores", observa a construção ideológica do Brasil como "país-jardim", produção mítica da sociedade autoritária e violenta que "nos lança no reino da Natureza, fora do mundo da História". ${ }^{27}$

E é ainda com Raymond Williams que o tema e a violenta operação ganham mais esclarecimentos. Estudando "as modificações ocorridas nas atitudes em relação à paisagem na Inglaterra nos séculos XVIII e XIX”, lembra o autor que

É igualmente significativo que a história da paisagem inglesa no século XVIII seja tradicionalmente vista por uma perspectiva distorcida, a qual chega a dar a impressão - aliás, isto é dito e repetido - de que o proprietário rural setecentista, através dos paisagistas por ele contratados e com o auxílio dos poetas e pintores, inventou a

25 WILliAMS, Raymond. "Ideias sobre a natureza". in: Cultura e Materialismo. São Paulo: Editora Unesp, 2011, p. 108.

26 WILliaMS, Raymond. O Campo e a Cidade: na história e na literatura. São Paulo: Cia das Letras, 2011, pp. 213-240.

27 CHAUI, Marilena. “O que comemorar?”. in: Projeto História, São Paulo, n. 20, abr. 2000, p. 51. 


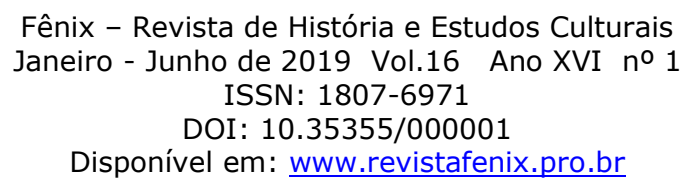

beleza natural. E, de certo modo, por que não? Dentro da mesma visão ideológica, ele inventou a caridade, o melhoramento da terra e a polidez, do mesmo modo como ele e seus semelhantes foram para terras de outros homens e, dessa forma, "descobriram" essas terras. ${ }^{28}$

Contribuem as problematizações desses autores para pensarmos perspectivas de análise que superem divisões quanto ao que seja a natureza e o meio social de sua produção. Importante ainda observar com Milton Santos que em se tratando de "meio ambiente" forçoso é considerar que antes da palavra "ambiente", vem "meio", o qual é conformado no espaço do trabalho. ${ }^{29}$

Ainda nessa direção, das relações entre natureza, cultura e trabalho, propõem Peter Linebaugh e Marcus Rediker relevante reflexão sobre aspectos centrais na produção social do capital na Inglaterra do século XVII. Tratam os autores da criação de portos para o comércio de longa distância e da limpeza da terra para a agricultura comercial naquele período, observando que

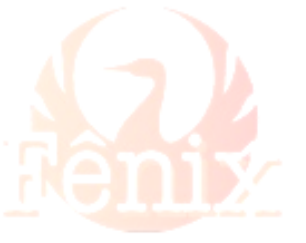

para os rachadores de lenha e tiradores de água africanos, europeus e americanos do começo do século XVII [trabalhadores que cumpriram função essencial na constituição da nova ordem do capital naquele momento], o trabalho era ao mesmo tempo maldição e castigo. Esses trabalhadores eram indispensáveis ao crescimento do capitalismo, fazendo o trabalho que não poderia ser feito, e nem o seria, por artesão em oficinas, fábricas ou guildas. Rachadores de lenha e tiradores de água desempenhavam as atividades fundamentais de expropriação que geralmente os historiadores nem sequer discutem. A expropriação, por exemplo, é tratada como coisa dada: o campo está lá antes que o arado comece; a cidade está lá antes que o trabalhador inicie o dia de trabalho; a colônia está lá antes que o escravo cultive a terra. É como se as mercadorias do comércio se transportassem a si mesmas. Finalmente, assume-se que a reprodução é a função trans-histórica da família. O resultado é que os rachadores de lenha e os tiradores de água são invisíveis, anônimos e esquecidos, apesar de terem transformado a face da Terra construindo a infra-estrutura da 'civilização'. ${ }^{30}$

28 WILLIAMS, Raymond. O Campo e a Cidade: na história e na literatura. São Paulo: Cia das Letras, 2011, p. 201.

29 SANTOS, Milton. A questão do meio ambiente: desafios para a construção de uma perspectiva transdiciplinar. in: Interfacehs, São Paulo, v. 1, n. 1, ago 2006, p. s/n. Disponível em: http://www3.sp.senac.br/hotsites/blogs/InterfacEHS/wp-content/uploads/2013/07/2006-v1-trad-1.pdf. Acesso em: 21 de ago. 2017.

30 LINEBAUGH, Peter e REDIKER, Marcus. A hidra de muitas cabeças. Marinheiros, escravos, plebeus e a história oculta do atlântico revolucionário. São Paulo: Cia das Letras, 2008, p. 52. 
Os processos trabalhistas da Junta de Itacoatiara evidenciam nas práticas dos empreiteiros derrubadores da mata atividades geralmente desconsideradas pelos estudos acadêmicos e, que, no entanto, são constitutivas das condições de avanço do capitalismo na Amazônia, pela expansão do agronegócio e do latifúndio alicerçados na precarização e terceirização do trabalho, eventualmente com o aval da Justiça.

Também importante pesquisa no sentido da superação de dicotomias na relação entre cultura, sociedade e natureza na região amazônica fez Maria Antonieta Antonacci em seus estudos de revalorização da experiência de índios, seringueiros e outros trabalhadores extrativistas do estado do Acre na década de 1970. Observa a autora que, "radicados em suas culturas e modos de trabalhar na floresta", 31 homens, mulheres, velhos e crianças da Amazônia resistiram naquele momento de ditadura no Brasil pela criação e defesa de direitos em torno do que inventaram em seu movimento como biodiversidade, dimensão social indissociável das suas lutas pelo direito ao trabalho na mata. $^{32}$

\section{A Justiça do Trabalho e as Juntas de Conciliação e Julgamento}

A instituição da Justiça do Trabalho no Brasil (prevista na Constituição Federal de 1934 e regulamentada em 1939, pelo Decreto-Lei n. 1.237, de 02 de maio), bem como das Juntas de Conciliação e Julgamento (Decreto n. 22.132, de 25 de novembro de 1932), remonta à ditadura do Estado Novo, e sua preparação corporativista-liberal desde o golpe de Estado de 1930 (o Decreto n. 19.770, de 19 de março de 1931, estabeleceria, já nos primeiros meses da "revolução", as diretrizes da nova estrutura sindical, com o agenciamento estatal dos sindicatos e de outras associações de classe, sendo ainda aprofundado esse controle a partir de 1939). Daí a perseguição sistemática a todas as formas de auto-organização dos trabalhadores brasileiros, e a instituição de legislação trabalhista específica para atender àqueles fins conciliatórios e colaborativos.

31 ANTONACCI, Maria Antonieta. Reservas extrativistas no Acre e biodiversidade: relações entre cultura e natureza. in: Projeto História, São Paulo, n. 18. Mai. 1999, p. 192.

32 Antes dessa reflexão, produziu a autora discussão relevante sobre formas de resistência e estratégias de "empate" de seringueiros acreanos pelo direito ao trabalho e contra a ditadura civil-militar no Brasil. Cf. ANTONACCI, Maria Antonieta. Cultura, trabalho, meio ambiente: estratégias de "empate" no Acre. Revista Brasileira de História, n. 28, São Paulo, ANPUH/Marco Zero, 1994, pp. 247-267. 


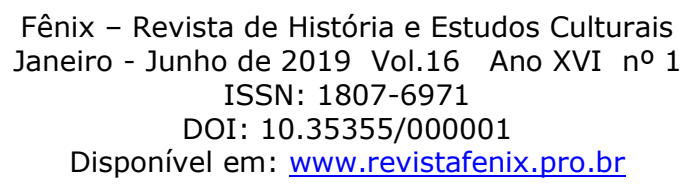

Kazumi Munakata faz relevante reflexão sobre os esforços da classe dominante do período para transformar patrões e trabalhadores em empregadores e empregados ${ }^{33}$ ou, como vemos nos processos aqui analisados, em reclamantes e reclamados. Predominam então perspectivas corporativistas e liberais no pensamento sobre o mundo do trabalho daquele momento, e de hoje, sob a máxima social de que "a liberdade de um termina quando começa a liberdade de outro". ${ }^{34}$ Tudo se passa como se, nas palavras de Linebaugh e Rediker mais acima referidas, a liberdade já estivesse lá antes de inventála as lutas de homens e mulheres pela superação da divisão de classes. Assim, Munakata destaca as formas "competentes", jamais cegas, de eliminação dessas resistências:

rápido exame das principais agências que constituem o arcabouço do Ministério do Trabalho permite vislumbrar o seu significado político que subsiste por trás da sua racionalidade, eficiência e neutralidade: eliminar qualquer possibilidade de conflitos trabalhistas. Mas, não eliminar cegamente: o impedimento da luta de classes se faz através da criação de canais competentes que absorvam os conflitos. Em outras palavras, procura-se exterminar a luta de classes retirando aos trabalhadores todas as possibilidades de controle e decisão sobre o seu próprio destino, confinando-os ao terreno da incompetência e da passividade. Os operários não precisam mais fazer nada, controlar nada, decidir sobre nada, lutar por nada: tudo está dado, rigorosa e cientificamente determinado por especialistas altamente competentes. ${ }^{35}$

Como desdobramento de atos legislativos da ditadura civil-militar de 1964, a Junta de Conciliação e Julgamento de Itacoatiara, será instituída pela Lei n. 5.644, de 10 de dezembro de 1970, no governo Médici, atrelada à Justiça do Trabalho da $8^{\text {a }}$ Região também criada neste ato, esta com sede em Belém do Pará, abrangendo sua jurisdição os estados do Amazonas, Acre, e os Territórios do Amapá e de Rondônia. Sob a jurisdição da Junta de Itacoatiara ficaram ainda os municípios de Nova Olinda, Borba, Autazes e Silves.

Com sede em Manaus, a Justiça do Trabalho da $11^{\text {a }}$ Região seria criada no

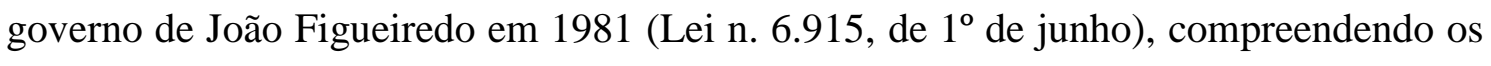
estados do Amazonas e do Acre, além dos Territórios do Amapá e de Rondônia.

\footnotetext{
33 MUNAKATA, Kazumi. A Legislação Trabalhista no Brasil. São Paulo: Brasiliense, 1981, p. 69.

34 Ibid., p. 12.

35 MUNAKATA, Kazumi. A Legislação Trabalhista no Brasil. São Paulo: Brasiliense, 1981, p. 78.
} 
Kazumi Munakata observa que a regulamentação da Justiça do Trabalho, após a promulgação da Lei de Segurança Nacional, em 04 de abril de 1935 (Lei n. 38), e demais instrumentos estatais de controle dos sindicatos, desvenda a lógica própria de gestão social, sob legislação e tendências políticas fortemente liberais (a Constituição de 1934, por exemplo, não reconhecia o direito de greve). ${ }^{36}$ A criação das Justiças do Trabalho nos estados do Pará e do Amazonas, e demais Juntas sob suas jurisdições, teria a finalidade, ao menos em princípio, de cumprir propósitos sociais nessa mesma linha. Registre-se, ainda, o vínculo orgânico entre as ditaduras vigentes no país durante o Estado Novo e após o golpe de 1964 e a edificação dos pilares fundamentais daquelas instituições de justiça.

Observamos sobre a documentação aqui analisada que a hegemonia do pressuposto técnico e racional sobre o político, marca do liberalismo e do discurso da competência, tem historicidade. ${ }^{37}$ Kazumi Munakata comenta que o empenho em "transformar uma questão política, de correlação de forças entre o trabalhador e o patrão, numa questão jurídica e técnica, com suas regras e normas só acessíveis aos especialistas", ${ }^{38}$ incluía também os vogais. ${ }^{39}$ As ideologias paritárias entre trabalhadores, Estado e empregadores precisaram, no entanto, ser disputadas inclusive nos meandros institucionais da própria justiça trabalhista. O período de 1973 a 1980 que abarca os processos judiciais da Junta de Itacoatiara aqui analisados demonstra, quanto ao papel desempenhado por vogais de empregados e de empregadores naquelas reclamatórias, perspectivas conciliatórias e corporativistas estáveis. Impera nesses termos de audiência o silêncio e a conveniência daqueles representantes, na fórmula repetida ad nauseam: "os vogais nada perguntaram".

Análise de documentação de momento anterior, de outro município e estado, também no período da ditadura civil-militar de 1964, sugere que o tema daqueles

36 Ibid., pp. 99-103.

37 CHAUI, Marilena. "O discurso competente". in: CHAUI, Marilena. Cultura e Democracia. O discurso competente e outras falas. São Paulo: Cortez, 2003, pp. 3-13.

38 MUNAKATA, Kazumi. A Legislação Trabalhista no Brasil. São Paulo: Brasiliense, 1981, p. 105.

39 Os vogais de "empregados" e de "empregadores", "juízes classistas", "leigos”, "não togados”, foram previstos no direito brasileiro na década de 1930, eleitos a partir de listas encaminhadas por sindicatos de trabalhadores e de patrões para um mandato temporário, nos moldes da representação paritária do corporativismo de Estado. Com a promulgação da Emenda Constitucional no 24, de 09 de dezembro de 1999, que extingue as Juntas de Conciliação e Julgamento, substituídas pelas Varas do Trabalho, é extinta também aquela função. 


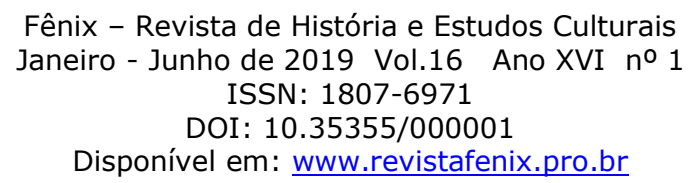

apaziguamentos liberais de representantes vogais passou por acomodações mais difíceis com o enfrentamento dos trabalhadores contra tentativas, eventualmente bem-sucedidas, de alinhamento da classe com os interesses do Estado.

Processos do ano de 1968, do Tribunal Regional do Trabalho/TRT da $2^{\text {a }}$ Região (São Paulo), em documentação preservada pelo acervo do Arquivo Edgard Leuenroth/Unicamp, registram movimentos de disputa de classe pela impugnação de vogais.

Em 16 de maio de 1968, o TRT de São Paulo acolhe a ação de impugnação do vogal dos empregados da Junta de Conciliação e Julgamento de Sorocaba, município do interior do estado. Trata-se de reclamatória subscrita por Damião e mais de uma centena de trabalhadores "de Sorocaba e demais localidades (Votorantim, Araçoiaba da Serra, Salto de Pirapora, Capela do Alto, etc.)", alegando

que foi motivo de estranheza e de revolta a recondução do Sr. Mateus para a função de vogal dos empregados tendo em vista o fato de não mais merecer a confiança dos empregados da Comarca, não ter sido indicado pelo Sindicato de sua categoria e não ter, ainda (apesar da época em que estamos) aprovadas as suas contas do exercício de 1967 eis que até setembro do referido ano foi Presidente do Sindicato dos Trabalhadores nas Indústrias da Construção e do Mobiliário de Sorocaba.

No conjunto de argumentos alegados nesse processo de impugnação, além da suposta falta de apoio do impugnado em sua própria categoria de trabalho (a dos escavadeiristas da indústria de cimento) e sua posterior indicação para o posto de vogal pelo Sindicato dos Enfermeiros e Empregados em Hospitais e Casas de Saúde de São Paulo (não existente na cidade de Sorocaba) arrolam ainda os impugnantes as seguintes ponderações:

não é menos verdade ainda que o Sr. Mateus está afastado da produção a cerca de 10 anos tendo nesse período recebido bonificação (salário e ajuda de custo) de seu Sindicato (Sindicato dos Trabalhadores nas Indústrias da Construção e do Mobiliário de Sorocaba) do qual era Presidente, e, há 6 anos, proventos da Justiça do Trabalho devido às suas funções de Vogal. Nas horas vagas exerce a função de motorista visto que possui um automóvel de aluguel (em nome de sua espôsa) no ponto da Matriz em Sorocaba. Além disso possui um caminhão em sociedade com Lucas [...] veículo esse que tem contrato de transporte com a S/A Indústrias Votorantim - Fábrica 


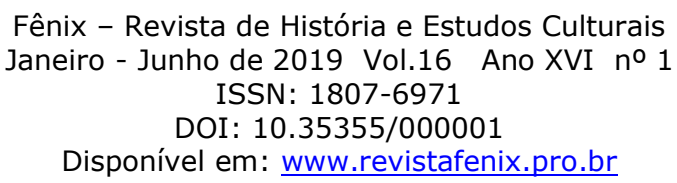

de Cimento Votoram, principal empregadora dos operários da categoria da qual era Presidente.

Entre outros pontos que fundamentam o processo, sinalizam os autores do processo “que existe uma 'gama' de elementos em melhores condições de ocupar a função do que o reconduzido". Por Mateus (alcunhado "Vogal do Amém”) não ter sido indicado por nenhuma das listas tríplices entregues à Justiça do Trabalho pelos dez sindicatos existentes em Soracaba, questionam: “será que o Egrégio Tribunal está subestimando a inteligência dos trabalhadores de Sorocaba?”. E continuam:

Tivesse sido indicado qualquer outro elemento e evitada a nociva recondução e os Trabalhadores de Sorocaba, neste momento, estariam aplaudindo e continuando a acreditar no Egrégio Tribunal e não pensando o que estão e não se pode dizer.

O Egrégio Tribunal do Trabalho da $2^{a}$ Região que é integrado pelos maiores luminares da ciência do Direito do Trabalho, a maioria deles mestres de Faculdades (em Sorocaba temos um exemplo) e com inúmeros trabalhos publicados têm se portado sempre com sabedoria e honradêz e não pode, com atitudes como esta, admitir que simples trabalhadores queiram passar-lhes atestado de ignorância e cheguem a presumir tenha agido com desonestidade.

A referência, nos autos, a própria classe como "simples trabalhadores" e "elementos" e a crítica à atividade do sindicalista e remunerações nesse meio faz pensar em correlações de força amplas, eventualmente com a participação de patrões interessados no pleito. Por meio de reportagens da imprensa periódica, anexadas ao processo, sobre supostos atos de repúdio na cidade contra a recondução do vogal à Junta de Conciliação e Julgamento de Sorocaba, os impugnantes apontam haver a demanda judicial alcançado grande repercussão.

A defesa de Mateus, em seu recurso, aponta estratégia de "blitzkrieg”, ataque massivo por meio de seis ações de impugnação. Observa ainda que:

O que as impugnações tinham por alvo era e é exatamente o contrário, ou seja desmoralizar a instituição [a própria justiça trabalhista], sobretudo na zona industrial de Sorocaba, cujas diretorias sindicais atualmente estão entregues à aventureiros, salvo raras exceções, profissionais do sindicalismo, estreitamente ligados a ideologia política há muito refugada pelo consenso unânime da sociedade. Contra a investidura do ora recorrente foram apresentadas seis (6) impugnações, todas datilografadas na mesma máquina de escrever em têrmos inteiramente idênticos e subscritas por categorias profissionais 


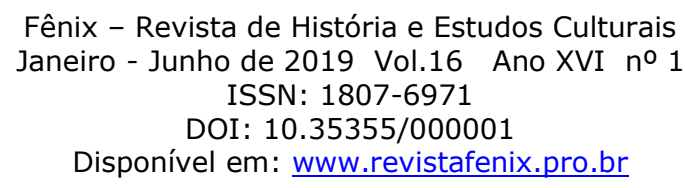

que recebem orientação jurídica de conhecido advogado da cidade, conhecido acima de tudo por sua tendência esquerdista.

Sentencia o Tribunal desfavoravelmente a Mateus impugnando-o daquela representação dos trabalhadores. Cabe aventar a hipótese de que no período, junho de 1968 (o Ato Institucional n. 5 seria decretado em 13 de dezembro, no governo de Costa e Silva), momento de forte repressão à classe trabalhadora no país, muitas vozes tenham se arvorado em representantes do operariado, ecoando eventualmente interesses de setores empresariais naqueles sindicatos de trabalhadores. Ainda outros processos desse mesmo período, reclamando a impugnação de vogais de empregados, explicitam apoio a intervenções de Juntas Governativas em sindicatos da região de Sorocaba, e disputas por grupos que nesse meio declaram-se alinhados ao "governo revolucionário" de então. Tais fontes evidenciam a prática cotidiana da Justiça do Trabalho durante aquela ditadura civil-militar como espaço de acomodação de interesses antagônicos da própria classe dominante, com a confirmação nesses autos processuais de que golpes de Estado se expressam por continua instabilidade, inclusive entre aqueles que os promovem.

A Junta de Conciliação e Julgamento de Itacoatiara, pela documentação e período aqui analisados, sugerem dimensões institucionais com acomodações do direito trabalhista no campo corporativista.

\section{A NATUREZA E O ESPAÇO SOCIAL DO TRABALHO}

As análises propostas na presente pesquisa partem de pressupostos teóricometodológicos articulados a determinada compreensão da invenção social do trabalho, e isso no sentido forte do termo, tomado esse processo, sem a pretensão de radiografias estáticas de cercamentos ${ }^{40}$ ou propriedades privadas. A apropriação, nesse caso, refere para a propriedade privada dos meios sociais públicos de produção, processo apenas apreensível em movimento contínuo, de posição e reposição de contradições. ${ }^{41}$ Nessa

40 Sobre o tema da formação dos direitos no espaço social de "cercamentos" e disputas entre senhores e caçadores nas "florestas do Rei" na sociedade inglesa do século XVIII, conf. THOMPSON, E. P. Senhores \& Caçadores. A origem da lei negra. Rio de Janeiro: Paz e Terra, 1997.

41 Pensamos aqui no conceito de Hegemonia/Contra-Hegemonia de Antonio Gramsci. Para aprofundamento do tema, conf. GRAMSCI, Antonio. Cadernos do Cárcere (vol. 4): Temas de cultura, ação católica, americanismo e fordismo. Rio de Janeiro: Civilização Brasileira, 2015 e CHAUI, Marilena. Conformismo e Resistência: aspectos da cultura popular no Brasil. São Paulo: Brasiliense, 1986, p. 22. 


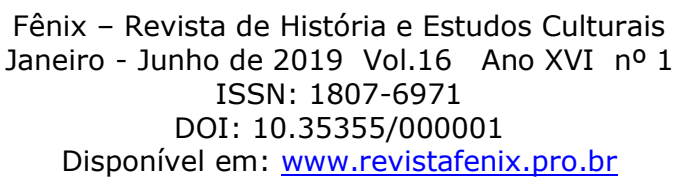

perspectiva, o tema da luta de classes implica no entendimento da condição de reposição contínua da divisão de classes por proprietários e patrões, haja vista serem os bens do capital apenas apropriáveis e passíveis de manutenção através da expropriação do trabalho alheio. Karl Marx explica essa dinâmica como central na formação do capital, o qual gera riqueza por concentrar os meios sociais públicos de produção pela força e pela violência, pela técnica e pela lei, ${ }^{42}$ estipuladas as devidas regras contratuais e remuneratórias, com acordos salariais e de tempo de serviço, mas na maioria das vezes sem sequer isso. O trabalho escravo no Brasil, bem como os contornos claros das margens de lucro nessas formas de exploração, é de memória recente, também na Amazônia. ${ }^{43}$ A problematização de processos e leis trabalhistas exige análises atentas a esse campo de relações, como disputas históricas marcadas pela desigualdade social na correlação de forças em jogo contra os trabalhadores e seus modos de vida, presentes ainda hoje pela prática do "regime do barracão". ${ }^{4}$

Assim, na Junta de Itacoatiara não são incomuns autos processuais que encaminham formalmente, no regime da consolidação das leis trabalhistas, reclamações que evidenciam trabalhos em difíceis condições, sem registro em carteira, com salários retidos por meses, dificuldades insuperáveis de transporte no deslocamento de áreas

42 MARX, Karl. Grundrisse. Manuscritos econômicos de 1857-1858. Esboços da crítica da economia política. São Paulo: Boitempo, 2011, p. 39.

43 Como desdobramento do golpe parlamentar-judicial de 2016 contra a presidenta Dilma Rousseff, o atual Ministério do Trabalho, pela Portaria $\mathrm{n}^{\mathrm{o}}$. 1.129, de 13 de outubro de 2017, altera os conceitos de trabalho forçado, jornada exaustiva e condições análogas a de escravo no Brasil. A partir dessa normativa, se um trabalhador for submetido a trabalho forçado "que lhe retire a possibilidade de expressar sua vontade", ou jornada exaustiva "com privação do direito de ir e vir", em condições degradantes "por atos comissivos de violação dos direitos fundamentais da pessoa", não poderá mais ser caracterizado como trabalhador escravo, definição que passa a exigir o "conjunto" desse quadro, e, ainda, "a manutenção de segurança armada com o fim de reter o trabalhador no local de trabalho em razão de dívida contraída com o empregador ou preposto". Dispõe também a Portaria, em seu Art. $4^{\circ}$, $\S 1^{\circ}$, e Art. $5^{\circ}$, que "a organização do Cadastro ficará a cargo da Secretaria de Inspeção do Trabalho (SIT), cuja divulgação será realizada por determinação expressa do Ministro do Trabalho", "publicada no sítio eletrônico do Ministério do Trabalho duas vezes ao ano, no último dia útil dos meses de junho e novembro". Assim, deixa de ser consolidada a "lista suja" dos empregadores criminosos por ato técnico e isento da equipe de fiscalização da pasta ministerial a qualquer tempo, independentemente da anuência do Ministro.

44 José de Souza Martins observa a prática do regime do barracão da economia da borracha, na Amazônia, como "uma forma de servidão que persiste no Brasil e representa a incorporação de mecanismos de acumulação primitiva na formação e disseminação da grande e até moderna empresa agrícola, extrativa e pecuária. Em ambos os casos, o próprio empresário criou inventivamente ajustamentos econômicos que lhe permitiam ganhar como capitalista e pagar como senhor de escravos, embora livre da renda capitalizada representada pela imobilização de capital no verdadeiro escravo, uma tênue mudança em relação ao regime de escravidão". MARTINS, José de Souza. O cativeiro da terra. São Paulo: Contexto, 2010, p. 34. 
remotas de empreitadas "terceirizadas" de "derrubada da mata" até a sede de origem, sem alimentação, com risco à saúde e sem direito ao descanso, "quebras contratuais" eventualmente ajustadas e conciliadas em audiências.

Em 21 de outubro de 1974, Domingos, "braçal, solteiro, brasileiro", reclama contra empresa agroindustrial a assinatura de sua carteira de trabalho. Tendo iniciado o contrato com a empresa em 01 de julho de 1974, Domingos é acidentado em 10 de setembro do mesmo ano. Da audiência ocorrida em 31 de outubro, temos inicialmente a contestação da empresa, "uma vez que o reclamante não era seu empregado". Interrogado informa o trabalhador

que foi levado para trabalhar por um Sr. de nome Antônio e quem o transportou ao local de serviço, foi um fiscal da reclamada de nome João; que acidentou-se no serviço a 10/09/74; que o fiscal da reclamada disse ao depoente que esta faria jus ao seguro acidente o que entretanto não ocorreu; que até hoje continua sem trabalhar em face do acidente, que a reclamada não anotou sua carteira (...).

E iniciam-se nesse ponto as evasivas quanto às responsabilidades pelo ressarcimento daqueles direitos.

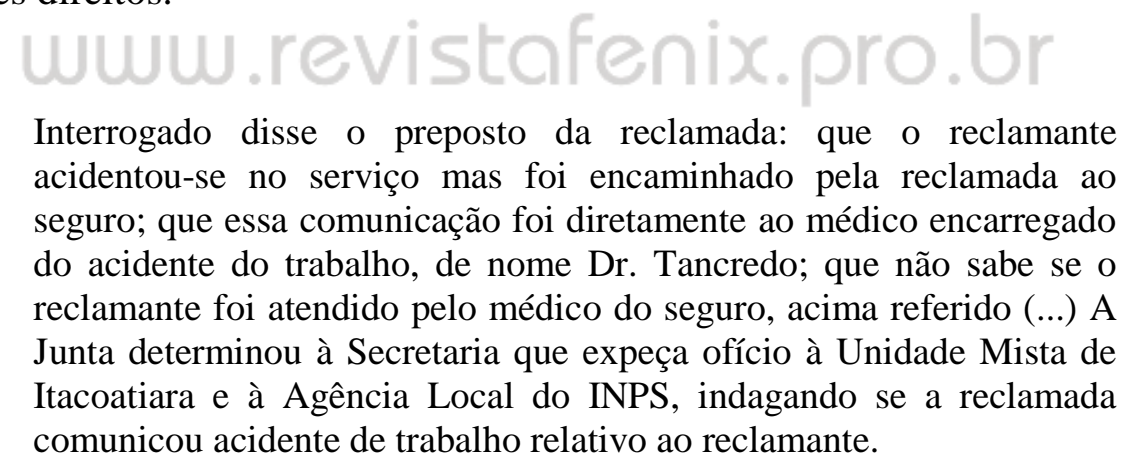

A empresa arrola testemunha, e em 22 de novembro de 1974, após serem desmarcadas duas audiências por conta do seu não comparecimento, sabemos que

Interrogado disse a testemunha do reclamado: Sr. Julio (...) trabalha há quase dois anos para a reclamada, primeiro como empreiteiro e há cerca de cinco meses como empregado; que a sua carteira de trabalho ainda não foi anotada porque está aguardando a solução de um problema com o instituto; que conhece o reclamante e sabe que o mesmo trabalhou com o empreiteiro; que o reclamante fazia roçagem e derrubada de mata nos terrenos da empresa; que a reclamada faz esses serviços através dos empreiteiros que contrata; que na fazenda da reclamada trabalham doze empreiteiros, que fazem o serviço de derrubada; que esses empreiteiros que contratam os trabalhadores; que 


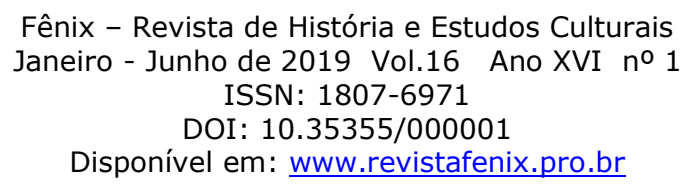

a empresa fornece a verba; de acordo com o saldo de cada empreiteiro e este efetua o pagamento dos trabalhadores, que quando um trabalhador sofre um acidente a reclamada só se responsabiliza se um deles for seu empregado; que nem um dos trabalhadores que fazem serviço de derrubada são empregados da reclamada; que tem conhecimento que o reclamante teve uma fratura no braço quando em serviço; que o depoente é o fiscal de serviço; que fiscaliza o serviço dos empreiteiros, se está bom ou se a produção satisfaz; que no dia do acidente do reclamante, o depoente foi avisado pelo empreiteiro; que o fato foi comunicado ao gerente da reclamada e que este determinou que fosse encaminhado para o hospital de Itacoatiara, que a reclamada faz um seguro de vida no INPS para os empregados avulsos que trabalhavam com o empreiteiro, que segundo soube na empresa que o seguro desses trabalhadores avulsos significa apenas o tratamento médico, nos casos de perigo, nos casos mais graves, devem receber seguro, que o contrato da reclamada com o empreiteiro R. M. é verbal; que o Sr. R. M. não tem firma reconhecida e nem condições econômicas para atender os trabalhadores como o reclamante (...)

Em 29 de novembro de 1974 sentencia o juiz da Junta de Itacoatiara:

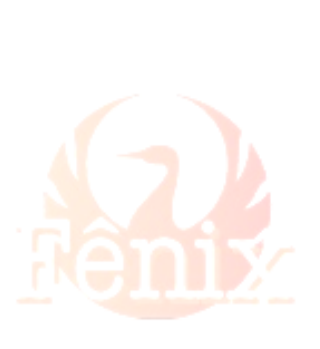

Fundamentação

(...) o reclamante era realmente um empregado da reclamada, de vez que possuía todos os requisitos previstos no art. $3^{\circ}$ da CLT, como seja: seu trabalho era pessoal, contínuo, oneroso e sujeito à subordinação hierárquica. $\mathrm{O}$ reclamante faria serviço de roçagem e derrubada da mata, os quais eram imprescindíveis à finalidade da empresa, tanto assim que esses serviços eram fiscalizados ultimamente pela testemunha.

E segue:

Em caso de acidente de trabalho a reclamada era imediatamente informada para tomar as providências cabíveis, como aconteceu com o reclamante, segundo declarou em seu depoimento o representante da reclamada. Logo aí se vê a contradição, não fosse o autor empregado da reclamada, por que razão assumiu a responsabilidade de encaminhamento ao serviço médico?

Nesse processo, sem que em momento algum se questione sobre remuneração, gravidade do acidente, auxílio-doença, indenização ao trabalhador por seu afastamento compulsório de qualquer atividade remunerada até aquele presente, ou detalhamento sobre a legalidade daquelas derrubadas, título de propriedade de terras, ou tipificação de atividade degradante "imprescindível à finalidade da empresa", impõe a Justiça apenas a obrigatoriedade de "assinatura de carteira". Em suma, o ajuste é burocrático e legitimador de todos os silêncios que cercam esse afastamento por fratura no braço, 


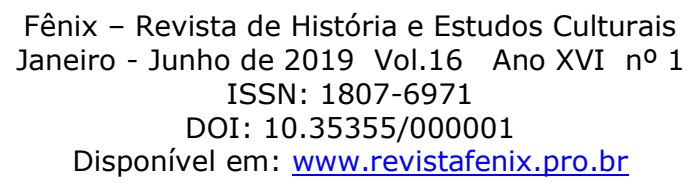

seguido de internação prolongada com sequelas graves até o momento da audiência, portanto, supostamente visíveis ou verificáveis sem grandes apuros técnicoprevidenciários.

O controle dos desdobramentos judiciais nesses processos, ao menos no nível da anotação escrituraria dessas páginas, parece evidente, eventualmente com vistas a evitar quaisquer contratempos financeiros à empresa. As audiências (ou ao menos o que nos aponta a narrativa escrita desses atos) não contraditam tais pressupostos. O não aprofundamento das condições concretas daquela disputa ou defesa de direitos sociais aí ameaçados marcam procedimentos regulares daquela justiça, sem que vogais presentes questionem ou se manifestem. A operação é técnica.

Contudo, nesses processos insinuam-se vozes dissonantes, momentos em que as anotações de técnicos e outros operadores da justiça evidenciam pela escrita detalhada as contradições presentes e alcances concretos da exploração do trabalho na região.

Em 20 de agosto de 1980, Pedro, trabalhador na "roçagem de capoeira", reclama contra D. T., o pagamento de "aviso prévio, $13^{\circ}$ salário, férias proporcionais, salário retido, horas extras, anotações de carteira, juros e correção monetária”, somando $\mathrm{Cr} \$ 16.882,80$ o total dessa demanda pelo período de cinco meses de serviços prestados.

Informa Pedro que

o reclamado lhe prometeu no início do trabalho que lhe pagaria 40,00 por dia até o dia 02 de agosto, dessa data em diante iria pagar-lhe 70,00 diário, mas que nunca lhe pagou esse salário; o reclamante tirava rancho na casa do reclamado; num dia qualquer o reclamado somou sua conta lhe restando de saldo 1,00; o reclamado lhe prometeu dar uma surra, que também disse a todos os seus empregados, inclusive o reclamante, soltar uma bomba para matar a todos; o reclamante trabalhava em roçagem de capoeira, deixando tudo, com medo da bomba e veio para a cidade de motor de linha, não tem CTPS mas garantiu trazê-la para anotação no dia da audiência; que o reclamado reside no lago do Siripá, Mun. de Itacoatiara, porém, o reclamante se comprometeu em avisar na Justiça, assim que o motor do reclamado chegue nesta cidade; fazia uma hora extra todos os dias.

Tais ameaças, de "surra" e "bomba para matar a todos", motivos pelos quais, diz o trabalhador, deixar "tudo, com medo da bomba e veio para a cidade de motor de linha”, não foram suficientes, ao que parece, para que nesse processo se indicasse a necessidade e urgência de investigações no referido local de trabalho. Ausentes 
trabalhador e patrão na audiência designada de conciliação e julgamento, o caso é arquivado pelo juiz.

Observamos que as reclamações judiciais movidas pela classe trabalhadora da região, nestas e em outras autuações trabalhistas, indicam luta por justiça e intervenção no espaço formal daqueles operadores do direito. Daí a importância da análise dessas fontes para que não se homogeneíze o entendimento de práticas e experiências diversas no campo da resistência de classes. Também esses trabalhadores participaram da construção histórica dos direitos fundamentais e possibilidades de sua regulamentação no Direito brasileiro, enfrentando ativamente a sua construção nos foros da justiça. Foi ainda a partir da resistência expressiva de movimentos sociais que lutaram contra a ditadura civil-militar que esses pressupostos políticos se impuseram também no campo das ciências jurídicas no Brasil, tendo sido igualmente disputados por trabalhadores e trabalhadoras amazonenses no cotidiano da Junta de Conciliação e Julgamento de Itacoatiara nas décadas de 1970 e 1980. Apoiados aqui em Dalmo de Abreu Dallari, partimos do pressuposto de que tais direitos sociais, garantias do direito à vida e ao trabalho, podem e devem ser postulados pelos operadores da justiça, seja qual for a sua matéria de competência, como fundamento da democracia. ${ }^{45}$

45 DALLARI, Dalmo de Abreu. Direitos humanos e cidadania. São Paulo: Moderna, 1982. 